\title{
PERTUMBUHAN Kappaphycus alvarezii DENGAN PENAMBAHAN EKSTRAK Sargassum aquifolium
}

\section{GROWTH PERFORMANCE OF Kappaphycus alvarezii WITH ADDING Sargassum aquifolium EXTRACT}

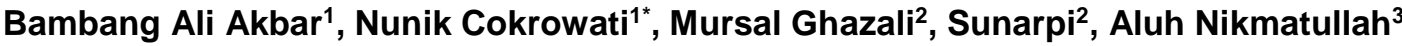 \\ ${ }^{1}$ Program Studi Budidaya Perairan, Universitas Mataram JI. Majapahit No. 62 Mataram \\ ${ }^{2}$ Fakultas MIPA, Universitas Mataram JI. Majapahit No. 62 Mataram \\ ${ }^{3}$ Fakultas Pertanian, Universitas Mataram Jl. Majapahit No. 62 Mataram \\ ${ }^{*}$ Corresponding author e-mail: n_cokrowati@icloud.com
}

Received: February 14, 2016/Accepted: March 29, 2016

\begin{abstract}
ABSTRAK
Tujuan penelitian ini adalah mempelajari pengaruh penggunaan Sargassum aquifolium dengan konsentrasi dan lama waktu perendaman yang berbeda terhadap pertumbuhan Kappaphycus alvarezii, serta mengetahui pengaruh penggunaan S. aquifolium terhadap persentase kadar karaginan K. alvarezii. Penelitian menggunakan Rancangan Acak Lengkap (RAL) dengan perlakuan faktorial yang terdiri dari dua faktor yaitu faktor 1 berupa konsentrasi ekstrak Sargassum aquifolium dan faktor 2 berupa perlakuan lama perendaman. Faktor 1 terdiri atas 4 perlakuan konsentrasi perendaman yaitu kontrol (K0), konsentrasi 5\% (K1), 10\% (K2), 15\% (K3). Faktor 2 terdiri atas 3 taraf yaitu lama perendaman 30 menit (T1), 60 menit (T2) dan 90 menit (T3). Data variabel penelitian dianalisis menggunakan analisis sidik ragam (ANOVA) pada taraf kesalahan 5\%. Hasil penelitian menunjukkan bahwa pemberian ekstrak Sargassum aquifolium tidak memberikan pengaruh terhadap pertumbuhan rumput laut Kappaphycus alvarezii. Perlakuan K1T3 (perendaman dengan konsentrasi 5\% selama 90 menit) menunjukkan hasil tertinggi dari perlakuan lainnya, nilai laju pertumbuhan spesifik $6.11 \%$, pertumbuhan mutlak $663.89 \mathrm{gram}$, berat kering $197.80 \mathrm{gr}$ dan nilai kadar karaginan yaitu $53.33 \%$. Berat kering terendah diperoleh pada perlakuan K3T3 (perendaman dengan konsentrasi 15\% selama 90 menit). Kesimpulan penelitian ini adalah pemberian ekstrak Sargassum aquifolium tidak memiliki pengaruh nyata terhadap pertumbuhan Kappaphycus alvarezii dan kadar karaginan tertinggi adalah 53.33\% terdapat pada perlakuan konsentrasi ekstrak Sargassum aquifolium 5\% dengan perendaman selama 90 menit.
\end{abstract}

Kata Kunci: berat kering, ekstrak, karaginan, perendaman, pertumbuhan.

\section{ABSTRACT}

This research purpose is to study the effect of adding Sargassum aquifolium extract dan time of submersion for growth performance and carrageenan content of Kappaphycus alvarezii. This research used completely randomized design with factorial treatment, consist of two factors. The first factor is concentrations of Sargassum aquifolium extract. The second factor is time of submersion. The first factor consist of 4 treatments are control (KO), consentrasion 5\% (K1), $10 \%$ (K2), $15 \%$ (K3). The second factor consist of submersion time of 30 minutes (T1), 60 minutes (T2) dan 90 minutes (T3). Variable datas of this research was analized using ANOVA (Analysis of Variance) at 5\%. The result showed that Sargassum aquifolium extract was not significantly affected growth performace of Kappaphycus alvarezii $(P>0,05)$. K1T1 (submersion with a concentration of $5 \%$ during 90 minutes) showed the higest results from other treatments, specific growth $6.11 \%$, absolute growth $663.89 \mathrm{~g}$, dry weight $197.80 \mathrm{~g}$ and carrageenan content $53.33 \%$. The lowest dry weight is K3T3 (submersion with a concentration of $15 \%$ during 90 minutes). The conclusion are Sargassum aquifolium extract did not have any real effect on performance growth of Kappaphycus alvarezii and the highest levels of $53.33 \%$ carrageenan contained in the treatment Sargassum aquifolium extract concentration of 5\% with submersion time of 90 minutes.

Keywords: carrageenan, dry weigth, extract, growth, submersion. 


\section{PENDAHULUAN}

Rumput laut komoditas perikanan unggulan dan merupakan komoditas yang dibudidayakan, dari 10 komoditas perikanan unggulan budidaya. Pada 2009 produksi rumput laut di Indonesia mencapai 2,5 juta ton dan diproyeksikan mencapai 10 juta ton pada tahun 2014 atau mengalami kenaikan rata-rata 32\% per tahun (Kordi, 2011). Rumput laut digunakan sebagai bahan baku baik pada industri makanan, kimia, kosmetik maupun obat-obatan (Aslan, 1998).

Meningkatnya permintaan rumput laut membuat usaha budidaya rumput laut di Indonesia semakin berkembang. Kondisi ini membuat Indonesia menyediakan beberapa kawasan sebagai sentra budidaya rumput laut diantaranya Nusa Tenggara Barat (NTB), Nusa Tenggara Timur (NTT), Sulawesi, Sumatra, Jawa dan Bali. Di NTB terdapat 10 Kawasan Minapolitan rumput laut yaitu Desa Pengantap (Kabupaten Lombok Barat), Teluk Gerupuk (Kabupaten Lombok Tengah), Teluk Ekas, Teluk Serewe (Kabupaten Lombok Timur), Kertasari (Kabupaten Sumbawa Barat), Labuan Mapin (Kabupaten Sumbawa), Kecamatan Terano, Kwangko (Kabupaten Dompu) dan Waworada (Kabupaten Bima). Namun potensi yang dapat dimanfaatkan di kawasan NTB masih belum optimal. Oleh karena itu, perlu dilakukan percepatan dan peningkatan produksi rumput laut mengingat kebutuhan dunia akan komoditi ini terus meningkat (DKP-NTB, 2010).

Kappaphycus alvarezii merupakan rumput laut yang mempunyai nilai ekonomis. Hidrokoloid yang terkandung didalamnya dapat digunakan sebagai bahan baku industri farmasi, kosmetik dan berbagai produk makanan (Mubarak et al., 1990 dalam Harnoto et al., 2015). Kappaphycus alvarezii merupakan salah satu komoditas prioritas karena memiliki beberapa keunggulan yaitu: teknologi budidayanya mudah dilakukan, modal yang diperlukan dalam budidaya rumput laut relatif kecil, usia panen singkat sehingga merupakan komoditas yang cepat untuk mengatasi kemiskinan serta kegiatan budidaya rumput laut hingga proses pengolahan pasca panen merupakan kegiatan yang padat karya. Sehingga rumput laut sering disebut komoditas yang memenuhi kriteria triple track: pro job, pro poor dan pro growth. Pada aspek budidaya rumput laut mampu menjadi kunci pemberdayaan masyarakat pesisir, selain itu permintaan pasar dunia masih tinggi (Mulyaningrum et al., 2013). Lebih lanjut dinyatakan oleh Indriani dan Sumarsih (1996) dalam Harnoto et al. (2015) jenis rumput laut ini diminati oleh masyarakat pesisir disebabkan teknologi budidayanya relatif mudah, waktu pemeliharaannya singkat dan biaya produksi relatif murah. Oleh karena itu, perlu dilakukan penelitian tentang pengaruh penggunaan Sargassum aquifolium terhadap pertumbuhan Kappaphycus alvarezii dan mengetahui persentase berat kering Kappaphycus alvarezii. Tujuan dari kegiatan penelitian ini adalah mempelajari pengaruh penggunaan $S$. quifolium dengan konsentrasi dan lama waktu perendaman yang berbeda terhadap pertumbuhan $K$. alvarezii serta mengetahui pengaruh penggunaan $S$. aquifolium terhadap persentase kadar karaginan $K$. alvarezii.

\section{BAHAN DAN METODE}

Penelitian ini dilaksanakan pada tanggal 07 Juni sampai dengan 27 Juli tahun 2015, bertempat di Dusun Ekas, Desa Ekas Buana, Kecamatan Jerowaru, Kabupaten Lombok Timur, Provinsi Nusa Tenggara Barat, sedangkan ekstraksi karaginan dilakukan di Laboratorium Biosains dan Bioteknologi Fakultas Pertanian, Universitas Mataram. Bahan yang digunakan diantaranya adalah bibit rumput laut $K$. alvarezii, $S$. aquifolium, $\mathrm{NaOH}$, aquades, kain kasa (kertas saring), aluminium foil, ethanol 96\%, tissu, air laut. Penelitian menggunakan Rancangan Acak Lengkap (RAL) dengan perlakuan faktorial yang terdiri dari dua faktor yaitu faktor 1 berupa konsentrasi ekstrak $S$. aquifolium dan faktor 2 berupa perlakuan lama perendaman. Faktor 1 terdiri atas 4 perlakuan konsentrasi perendaman yaitu 1 perlakuan sebagai kontrol (K0), perlakuan $5 \%(K 1)$, perlakuan 10\% (K2), perlakuan 15\% (K3). Faktor 2 terdiri atas 3 taraf yaitu lama perendaman 30 menit, 60 menit dan 90 menit. Data yang telah diperoleh, dianalisis menggunakan ANOVA (Analysis of Variance) dan dilakukan Uji lanjut BNT (Beda Nyata Terkecil) apabila terdapat pengaruh yang signifikan (berbeda nyata) dari setiap perlakuan. Parameter yang diamati adalah sebagai berikut: 


\section{a. Berat Kering}

Bibit rumput laut dengan berat awal penanaman $100 \mathrm{gr}$, diambil beberapa sebagai sampel berat kering dan dan berat basah. Nilai berat kering awal rumput laut dikeringkan dan ditimbang sedangkan untuk sampel berat kering akhir dilakukan pengeringan dan penimbangan setelah panen berlangsung. Perhitungan berat kering diperoleh dengan rumus sebagai berikut:

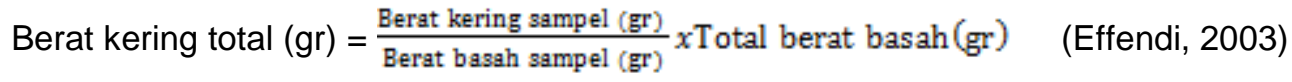

b. Laju Pertumbuhan Rumput Laut

Pertumbuhan mutlak diukur menggunakan rumus pertumbuhan mutlak yaitu:

$$
G=W_{t}-W_{0} \quad \text { (Effendi, 2003) }
$$

Dengan:

$\mathrm{G}=$ Pertumbuhan Mutlak Rata-Rata (\%);

$\mathrm{W}_{t} \quad=$ Berat Bibit Pada Akhir Penelitian (gr);

$\mathrm{W}_{0} \quad=$ Berat Bibit PadaAwal Penelitian (gr)

Laju Pertumbuhan Spesifik digunakan turunan dari persamaan Huisman yaitu:

$$
L P S=\frac{\operatorname{Ln} W t-\operatorname{Ln} W_{0}}{t} \times 100 \% \quad \text { (Effendi, 2003) }
$$

Dengan:

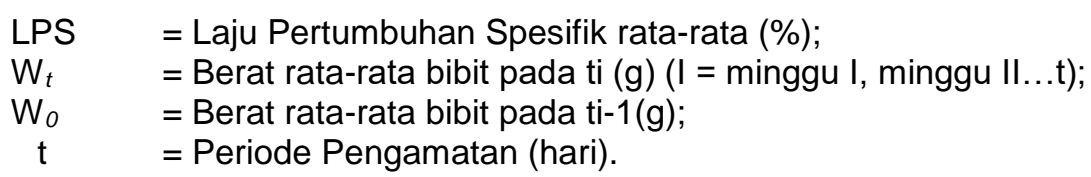

c. Hama dan Penyakit

Hama dan penyakit merupakan parameter pemeliharaan yang perlu diperhatikan, keberadaan hama dan penyakit biasanya diamati secara langsung (visual) selama pemeliharaan.

d. Pemeliharaan

Kegiatan pemeliharaan rumput laut berlangsung selama 49 hari yang diawali dengan penanaman bibit hingga pemanenan, kegiatan yang dilakukan selama penelitian yaitu pengukuran kualitas air, pengamatan hama dan penyakit, pembersihan rakit serta penimbangan sampel yang dilakukan setiap satu kali dalam 2 minggu.

e. Kualitas Air

Kualitas air yang diukur dalam penelitian ini meliputi Suhu air, $\mathrm{PH}$ air, Oksigen terlarut, Salinitas, Kecepatan arus, Kecerahan, N (Nitrogen) dan P (Posfor).

\section{HASIL DAN PEMBAHASAN}

\section{Pertumbuhan}

Hasil analisis data secara keseluruhan ditampilkan dalam bentuk Analysis of Variance (ANOVA) pada Tabel 1. 
Tabel 1. Analysis of Variance (ANOVA)

\begin{tabular}{ll}
\hline PARAMETER & HASIL ANOVA \\
\hline Laju Pertumbuhan Spesifik minggu ke-4 & NS \\
Pertumbuhan Mutlak minggu ke-4 & NS \\
\hline
\end{tabular}

Keterangan: $\mathrm{S}=$ Signifikan; NS = Non Signifikan

Berdasarkan hasil tabel Analysis of Variance (ANOVA) diatas tidak perlu dilakukan uji lanjut BNT (Beda Nyata Terkecil) karena hasil perhitungan menunjukkan bahwa pemberian ekstrak $S$. aquifolium tidak memiliki pengaruh yang signifikan terhadap pertumbuhan rumput laut $K$. alvarezii $(P>0,05)$.

Parameter pertumbuhan yang diamati dalam penelitian ialah pertumbuhan mutlak dan pertumbuhan spesifik. Pertumbuhan mutlak mengamati pertambahan berat rumput laut disetiap perhitungan sedangkan pertumbuhan spesifik mengamati persentase berat bobot setiap harinya. Belum ada penelitian sebelumnya mengenai hal ini.

\section{Laju Pertumbuhan Spesifik}

Pada perhitungan laju pertumbuhan spesifik selama 4 minggu terdapat nilai yang hampir sama yakni pada perlakuan dengan konsentrasi ekstrak 15\% yang direndam selama 30 menit (K3T1) memiliki nilai pertumbuhan harian $6,12 \%$ dan $6,11 \%$ pada perlakuan dengan konsentrasi $5 \%$ yang direndam selama 90 menit (K1T3). Sedangkan nilai pertumbuhan harian terkecil 5,84\% pada perlakuan (KOT1) yakni perlakuan kontrol yang hanya direndam selama 30 menit tanpa menggunakan ekstrak S. aquifolium (Gambar 1).

Pemberian ekstrak $15 \%$ dengan perendaman 30 menit dan pemberian ekstrak $5 \%$ dengan perendaman 90 menit memiliki nilai pertumbuhan spesifik yang baik dibandingkan dengan perlakuan lain selama pemeliharaan 4 minggu. Penggunaan konsentrasi ekstrak rendah dengan perlakuan waktu perendaman yang lama dan penggunaan konsentrasi ekstrak yang tinggi dengan mempersingkat lama waktu perendaman memiliki hasil yang lebih tinggi sehingga bisa dikatakan perbandingan antara lama perendaman dan jumlah ekstrak yang digunakan sangat berpengaruh terhadap hasil pada penelitian ini.

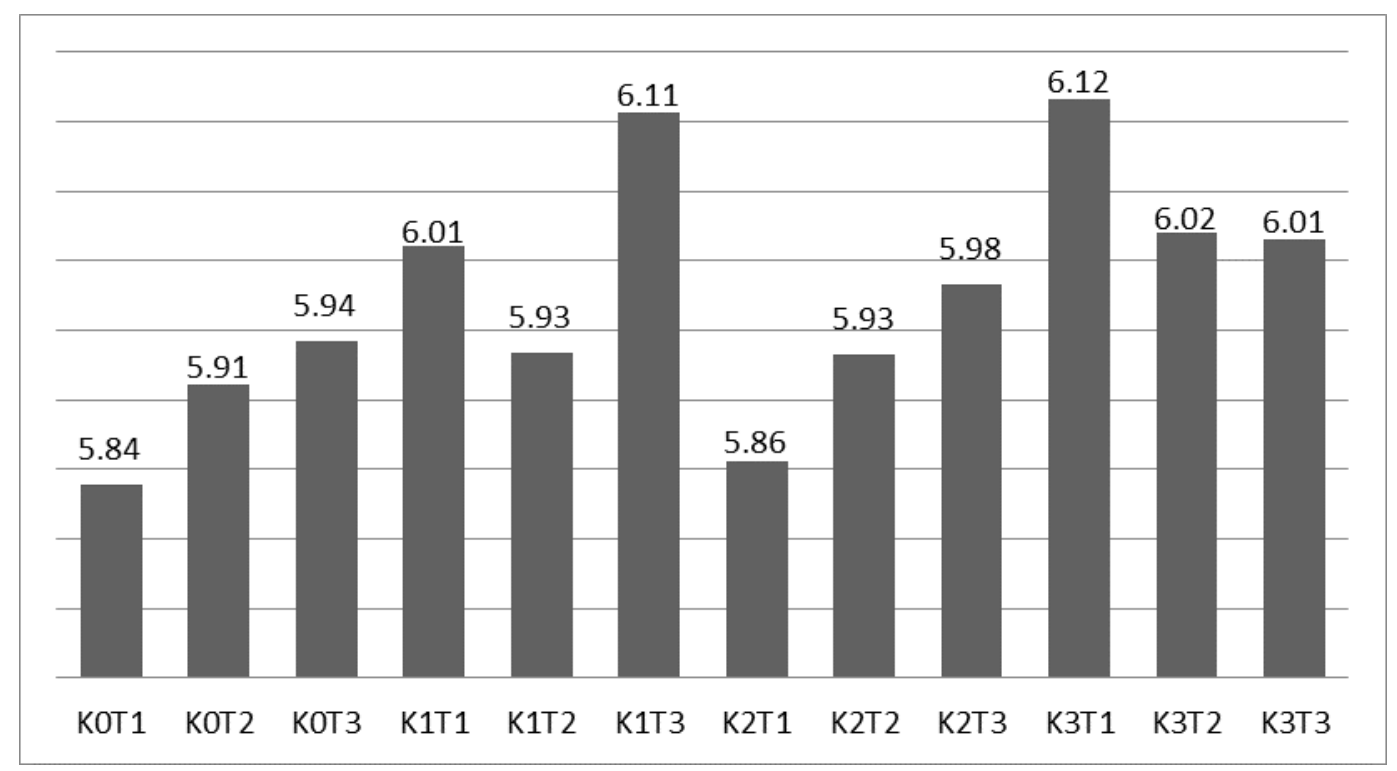

Gambar 1. Grafik laju pertumbuhan spesifik minggu ke-4 
ISSN: 1907-9931 (print), 2476-9991 (online)

Pemeliharaan selama 7 minggu memiliki nilai yang jauh lebih kecil dibandingkan waktu pemeliharaan 4 minggu (Gambar 2), ini bisa jadi disebabkan beberapa faktor yang diantaranya yaitu berat bobot rumput laut yang terlalu berat sehingga thallus mengalami kerontokan. Selain itu arus yang terlalu kuat mempercepat terjadinya kerontokan thallus. Perairan Ekas sangat cocok untuk dijadikan tempat budidaya rumput laut $K$. alvarezii dalam pertimbangan arus, karena selama penelitian berlangsung, kisaran rata-rata kuat arus perairan yaitu $20-40 \mathrm{~cm} /$ detik. Kuat arus berperan penting dalam budidaya $K$. alvarezii karena arus akan membawa nutrisi bagi tanaman, menyebabkan epifit, parasit dan kotoran serta benda asing lainnya yang akan hanyut oleh arus. Dengan demikian tanaman dapat tumbuh dengan baik karena ada kesempatan untuk menyerap nutrisi (makanan) dari air dan cahaya matahari agar proses fotosintesis tidak terganggu (Cokrowati, 2013).

Idealnya semakin banyak pemberian ekstrak $S$. aquifolium dan semakin lama perendaman maka akan semakin tinggi pula nilai pertumbuhan dari rumput laut tersebut, tetapi fakta dilapangan menunjukkan hasil yang diperoleh memiliki nilai tidak terlalu tinggi, kemungkinan ada kadar maksimum dan minimum yang harus diberikan pada perlakuan atau kemungkinan lama perendaman juga berpengaruh dan sampai saat ini belum ada penelitian yang menemukan kadar maksimum dan minimum penggunaan ekstrak $S$. aquifolium untuk pertumbuhan rumput laut, karena penggunaan dosis ekstrak yang terlalu tinggi juga dapat menjadi toksin atau masalah untuk pertumbuhan rumput laut tersebut.

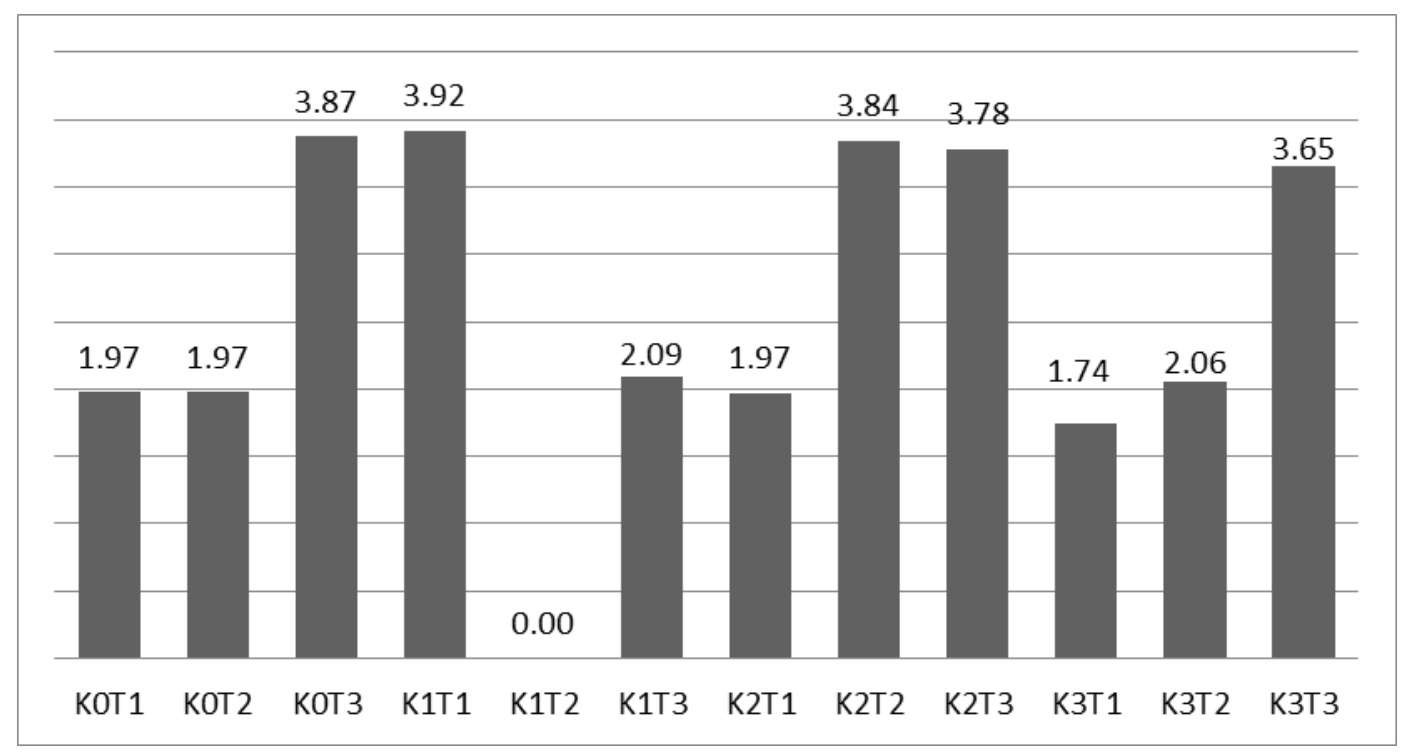

Gambar 2. Grafik laju pertumbuhan spesifik minggu ke-7.

\section{Pertumbuhan Mutlak}

Semakin besar nilai pertambahan berat tumbuh bibit maka semakin tinggi nilai laju pertumbuhan spesifik (harian). Pada grafik diatas, pertumbuhan mutlak selama 4 minggu, didapatkan hasil yang relatif sama dengan laju pertumbuhan harian yaitu tertinggi pada perlakuan dengan konsentrasi ekstrak $15 \%$ yang direndam selama 30 menit (K3T1) memiliki nilai pertumbuhan mutlak 676,67 gram, sedangkan perlakuan (K1T3) dengan konsentrasi 5\% yang direndam selama 90 menit memiliki nilai 663,89 gram selama pemeliharaan 4 minggu. Nilai pertumbuhan mutlak terendah ada pada perlakuan konsentrasi ekstrak 10\% dengan perendaman selama 30 menit (K2T1) yaitu 518,89 gram dan perlakuan kontrol (K0T1) yaitu 496,67 gram selama 4 minggu (Gambar 3).

Keadaan lingkungan yang kurang optimal dapat menyebabkan rumput laut tidak tumbuh bahkan menurun, hal tersebut dapat dipengaruhi oleh ombak dan pasang surut air laut, kecepatan arus, intensitas penyinaran matahari, kecerahan dan kandungan unsur hara yang terdapat di perairan. Hal ini sesuai dengan pendapat Aslan (1998) yang mengatakan bahwa umumnya $K$. alvarezii 
tumbuh dengan baik di daerah pantai terumbu (reef). Habitat yang sesuai adalah daerah yang memperoleh aliran air laut yang tetap, variasi suhu harian yang kecil dan substrat batu karang mati.Hal ini diperkuat juga oleh pendapat Cokrowati (2013), yang mengemukakan bahwa dalam pemilihan lokasi budidaya rumput laut perlu memperhatikan kuat arus perairannya. Kuat arus berperan penting dalam budidaya $K$. alvarezii karena arus yang baik akan membawa nutrisi bagi tanaman, karena rumput laut akan bersih dari kotoran maupun endapan yang menempel akan hanyut oleh arus. Dengan demikian tanaman dapat tumbuh dengan baik karena ada kesempatan untuk menyerap nutrisi (makanan) dari air dan juga proses fotosintesis tidak terganggu.

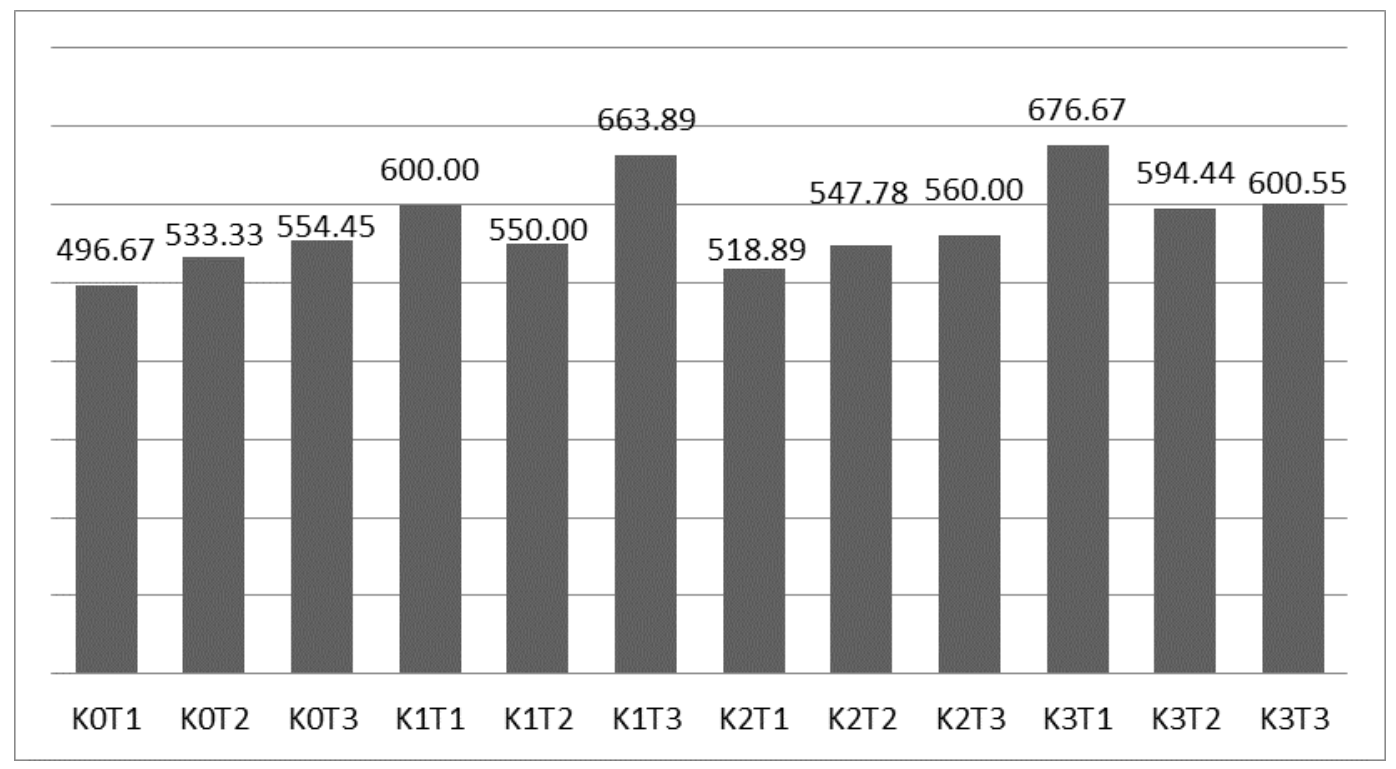

Gambar 3. Grafik pertumbuhan mutlak minggu ke-4.

Berat bibit berpengaruh terhadap pertumbuhan rumput laut $K$. alvarezii. Hal ini berkaitan dengan persaingan setiap individu rumput laut dalam mendapatkan unsur hara dan nutrien sebagai sumber makanannya. Berat bibit merupakan salah satu faktor teknis yang dapat berpengaruh terhadap pertumbuhan rumput laut dan juga jumlah kepadatan disetiap ikatan rumput laut perlu diperhatikan agar tidak terlalu padat sehingga dapat menyebabkan rumput laut rontok atau tali pengikat tidak kuat menahan bahan individu dalam satu ikatan sehingga rumpun akan terlepas dari tali.

Pada Grafik pertumbuhan mutlak selama 7 minggu (Gambar 4), perlakuan K1T2 memiliki nilai 0.00 yang disebabkan oleh bobot rumput laut yang terlalu berat sehingga ikatan tidak mampu menahan berat sehingga terlepas, dapat dilihat pada grafik pertumbuhan selama 4 minggu K1T2 memiliki nilai $550 \mathrm{gr}$. Jika ikatan tidak terlepas maka akan didapatkan nilai dua kali lipat dari nilai pengukuran akhir pada minggu ke-4. 
ISSN: 1907-9931 (print), 2476-9991 (online)

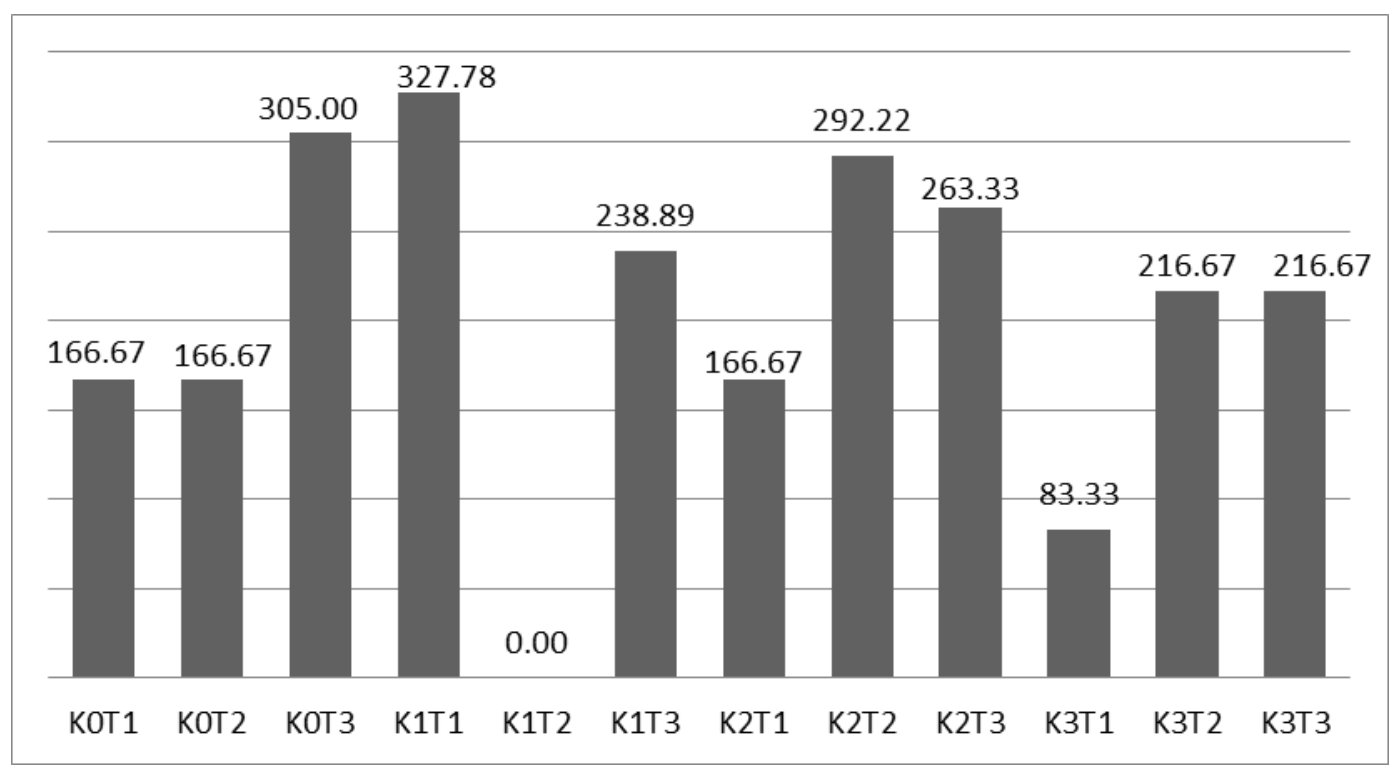

Gambar 4. Grafik pertumbuhan mutlak minggu ke-7

Laju Pertumbuhan Spesifik dan Pertumbuhan Mutlak menunjukkan bahwa semua perlakuan dengan konsentrasi dan perendaman yang berbeda memiliki pertumbuhan yang beragam, bisa saja disebabkan oleh kandungan ZPT yang terkandung dalam $S$. aquifolium berupa BAP yang berperan dalam memacu pertumbuhan, sesuai dengan pernyataan Sunarpi et al. (2010) dalam Ghazali et al. (2013) yang menyebutkan bahwa ekstrak dari Turbinaria muryana, Sargassum aquifolium, Sargassum cristaefolium, Sargassum crassifolium dan Hydroclathrus sp. mengandung bahan aktif Benzyl Amino Purine (BAP).

Menurut Dekker (1963) dalam Ghazali et al. (2013), secara fisiologis BAP berperan dalam memacu pertumbuhan tanaman, berkaitan erat dengan sintesis protein dan pembelahan sel serta mobilisasi nutrisi. Senada dengan Smith (1992) dalam Ghazali et al. (2013) mempertegas peranan ZPT terhadap pertumbuhan eksplan, sehingga dapat meningkatkan pembelahan sel, proliferasi pucuk dan morfogenesis pucuk. Menurut Franklin and Dixion (1993) dalam Andriana (2005) menyatakan bahwa BAP dalam konsentrasi 1-20 $\mu \mathrm{m}$ dapat menginduksi morfogenesis, dan bila konsentrasi ditingkatkan menjadi 20-50 $\mu \mathrm{m}$ maka dapat meningkatkan kecepatan multiplikasi tunas. Itu artinya, semakin banyak ekstrak $S$. aquifolium yang digunakan dalam perendaman maka akan semakin tinggi tingkat kecepatan multiplikasi tunas. Sedangkan pada penelitian ini perlakuan K3T1 menunjukkan hasil yang relatif tinggi dari perlakuan lainnya, baik dari hasil laju pertumbuhan spesifik, pertumbuhan mutlak, berat kering dan jumlah persen karaginannya. Namun nilai tertinggi terdapat pada konsentrasi $5 \%$ dengan perendaman selama 90 menit (K1T3), konsentrasi ini kemungkinan cocok untuk diaplikasikan untuk masyarakat, karena selain pertumbuhan tinggi perlakuan ini juga menghasilkan kadar karaginan yang tinggi.

\section{Berat Kering}

Berikut ini merupakan grafik berat kering yang diperoleh selama 7 minggu pemeliharaan (Gambar 5). Hasil perhitungan berat kering menunjukkan perlakuan (K1T3) 197,80 gram memiliki nilai tertinggi, dan hasil terendah diperoleh dari perlakuan (K3T3) yaitu 56,76 gram. Pada perendaman dengan ekstrak Sargassum aquifolium dengan konsentrasi $5 \%$ selama 90 menit, konsentrasi tersebut merupakan konsentrasi yang dapat ditolerir oleh Kappapicus alvarezii. Sehingga zat pengatur tumbuh dan nutrisi yang terkandung pada ekstrak Sargassum aquifolium berfungsi optimal dalam mendukung pertumbuhan Thallus Kappaphycus alvarezii. Sedangkan pada konsentrasi $15 \%$ dan lama perendaman selama 90 menit (K3T3), konsentrasi tersebut terlalu pekat bagi Kappaphycus alvarezii sehingga justru dapat mengkerutkan thallus dan dapat melembekkan thallus sehingga bagian permukaan thallus dapat meluruh. Hal itu menyebabkan berat basah dan berat kering menjadi lebih kecil dari perlakuan lainnya. 


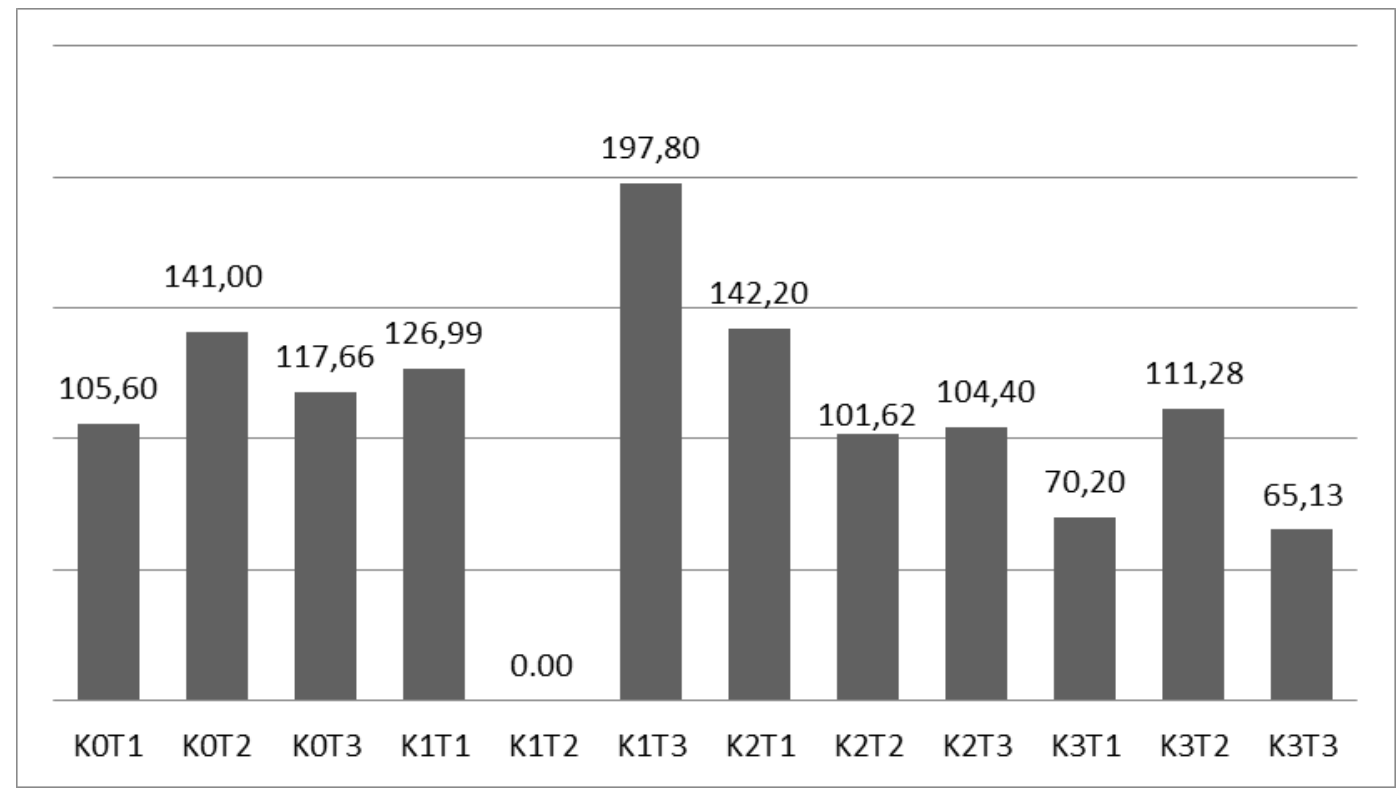

Gambar 5. Grafik berat kering

\section{Kadar Karaginan}

Kadar karaginan tertinggi didapatkan pada perlakuan (KOT3) atau perlakuan kontrol yaitu $56,67 \%$, sedangkan persentase kadar karaginan terendah diperoleh dari perlakuan K1T1 (perendaman dengan ektrak 5\% selama 30 menit) yaitu 34,50\% (Gambar 6).

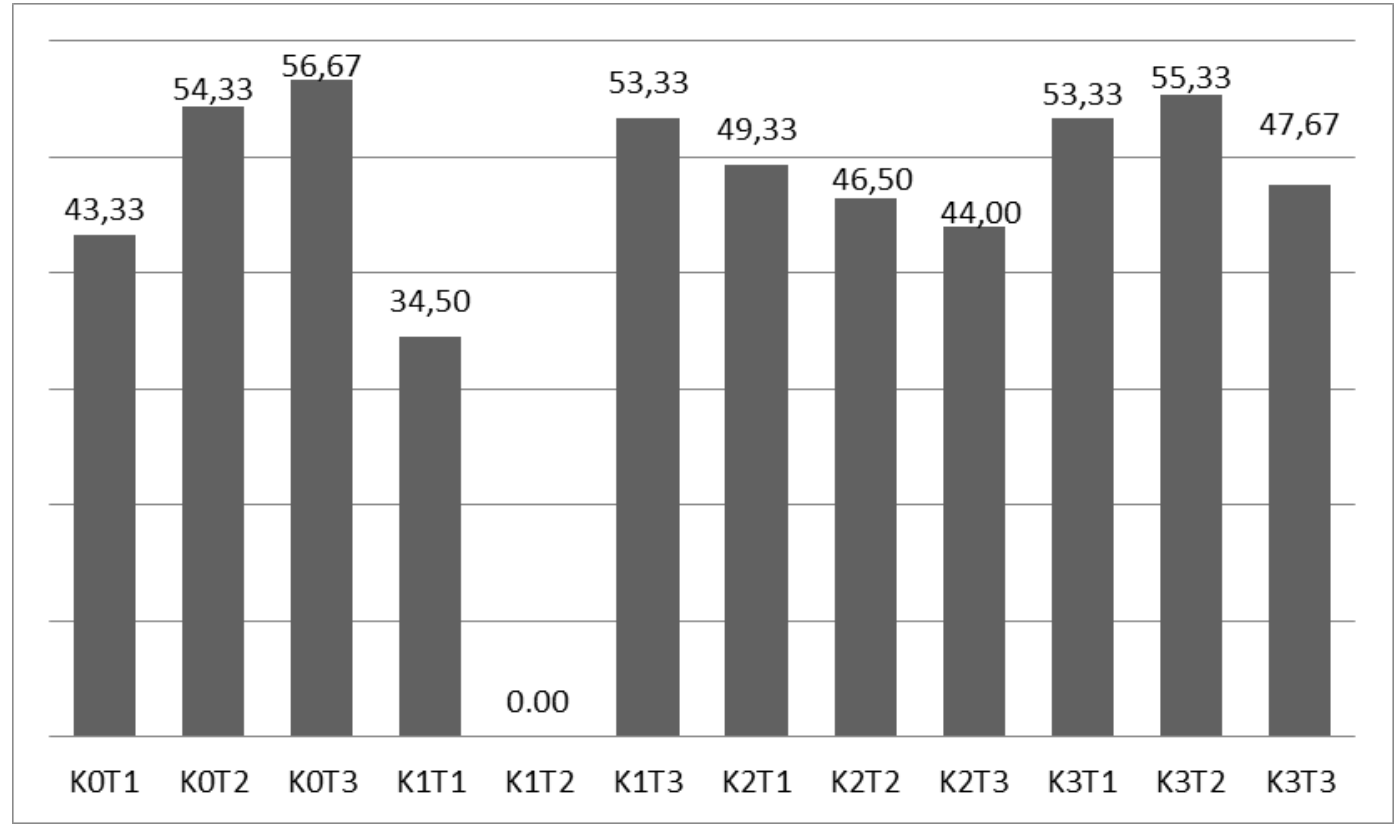

Gambar 6. Persentase kandungan karaginan

Kadar karaginan pada Kappaphycus alvarezii berkorelasi dengan pertumbuhan, berat kering dan umur panen. Pada bagian ujung thallus memperlihatkan pertumbuhan berat basah yang lebih tinggi akan menghasilkan berat kering dan kadar karaginan yang tinggi pula. Semakin tinggi berat kering rumput laut maka semakin tinggi pula kadar karaginannya. Jumlah dan kualitass karaginan yang berassal dari budidaya laut bervariasi, tidak hanya berdasarkan jenis melainkan juga umur tanam, sinar, nutrien, suhu, dan salinitas. 


\section{Kualitas Air}

Berikut adalah hasil pengukuran kualitas air (Tabel 2).

Tabel 2. Data kualitas air

\begin{tabular}{lllllll}
\hline Hari/Tanggal & Suhu & DO & Salinitas & PH & Kecerahan & Arus (m/dtk) \\
\hline Senin 22 juni & 27,2 & 7.9 & 33 & 8,3 & 1,5 & $5 / 25$ \\
Selasa 07 juli & 26,8 & 7.3 & 33 & 8,3 & 1,5 & $5 / 40$ \\
Senin 27 juli & 27,7 & 8 & 33 & 8 & 1,5 & $5 / 35$ \\
\hline
\end{tabular}

Selain pengukuran kualitas air diatas, dilakukan juga pengukuran kandungan NO3 - N dan PO4 $\mathrm{P}$ dengan hasil seperti terlihat pada Tabel 3 .

Tabel 3. Hasil NO3 - N dan PO4 - P

\begin{tabular}{lll}
\hline Parameter & $\mathbf{N O 3}-\mathbf{N}(\mathbf{M g} / \mathbf{l})$ & $\mathbf{P O 4}-\mathbf{P}(\mathbf{M g} / \mathbf{l})$ \\
\hline nilai & 1,7 & 0,45 \\
\hline
\end{tabular}

Aslan (1998), menyebutkan bahwa kadar nitrat terendah untuk pertumbuhan alga berkisar 0,30,9 mg/l. Riani (1994) dalam Yuliana et al. (2014) juga mengatakan kadar nitrat untuk mikroalga dapat tumbuh dan optimal pada kandungan nitrat 0,9-3,5 mg/l. Jika kadar nitrat dibawah 0,1 atau diatas $4,5 \mathrm{mg} / \mathrm{l}$, merupakan faktor pembatas pertumbuhan. Selain nitrat nutirent yang penting lain yang dibutuhkan untuk kelangsungan hidupnya yaitu fosfat, fosfat dapat menjadi faktor pembatas baik secara temporal maupun spasial karena sumber fosfat yang lebih sedikit diperairan.

Kondisi kimia yang mempengaruhi budidaya rumput laut antara lain yaitu suhu, salinitas dan DO. Salinitas yang dianjurkan untuk budidaya $K$. alvarezii adalah 28-35 ppt., karena rumput laut tumbuh pada salinitas yang tinggi. Penurunan salinitas akibat air tawar yang masuk akan menyebabkan pertumbuhan rumput laut menjadi tidak normal, sehingga untuk menghindari hal tersebut dianjurkan agar budidaya rumput laut sebaiknya memilih lokasi yang jauh dari mulut muara sungai (Cokrowati, 2013). Sesuai dengan lokasi penelitian saat ini yaitu perairan Ekas yang berlokasi jauh dengan mulut muara sungai dan rata-rata salinitas pada perairan Ekas selama penelitian yaitu 33 ppt. sesuai dengan persyaratan budidaya untuk K. alvarezii.

Kadar toleransi rumput laut terhadap kandungan karbondioksida terlarut bagi kelangsungan hidup rumput laut sangat baik bila berada pada kisaran $<1-3 \mathrm{mg} / \mathrm{l}$ sedangkan kandungan nitrat dalam kondisi berkecukupan biasanya berada pada kisaran antara 0,01-0,7 mg/l dan kandungan oksigen terlarut (DO) yang sangat sesuai untuk hidup rumput laut berkisar antara $4-10 \mathrm{mg} / \mathrm{l}$ (Effendy, 2003). Dengan demikian dapat dikatakan perairan Ekas memiliki tingkat kesuburan yang baik dan dapat digunakan untuk kegiatan budidaya rumput laut.

Kondisi lingkungan fisik yang mempengaruhi budidaya rumput laut antara lain kondisi dasar perairan, kecepatan arus, kedalaman air, suhu dan tingkat kecerahan. Bagi budidaya rumput laut K. alvarezii dasar perairan yang paling baik adalah dasar perairan yang stabil dan terdiri dari patahan karang mati (pecahan karang) dan pasir kasar serta bebas dari lumpur, dengan gerakan air (arus) yang cukup yakni arus yang tidak terlalu keras dan tidak terlalu tenang yang berkisar 20-40 cm/detik (Rasjid et al., 2001).

Keberhasilan budidaya rumput laut juga dipengaruhi oleh kedalaman air.Pada budidaya $K$. alvarezii dengan metode rakit apung, kedalaman air yang baik adalah antara 2-15 m pada saat surut terendah. Hal ini akan menghindari rumput laut mengalami kekeringan karena terkena sinar matahari secara langsung pada waktu surut terendah dan memperoleh penetrasi sinar matahari yang optimal secara langsung pada waktu air pasang (Cokrowati, 2013).

Suhu perairan yang baik untuk budidaya rumput laut adalah $20-28^{\circ} \mathrm{C}$ dengan fluktuasi harian maksimum $4^{\circ} \mathrm{C}$. Kenaikan temperatur yang tinggi mengakibatkan thallus rumput laut menjadi 
pucat kekuning-kuningan yang menjadikan rumput laut tidak dapat tumbuh dengan baik (Ditjenkan, 2012).

Kondisi air yang jernih dengan tingkat transparansi tidak kurang dari 2-5 m cukup baik untuk pertumbuhan rumput laut. Tingkat kecerahan yang tinggi berkaitan dengan penetrasi cahaya matahari kedalam air. Intensitas sinar matahari yang diterima oleh thallus merupakan faktor utama yang mempengaruhi proses fotosintesis (Prihaningrum et al., 2001).

Kondisi lingkungan biologi juga berpengaruh terhadap keberhasilan budidaya. Tempat budidaya $K$. alvarezii sebaiknya adalah perairan yang secara alami ditumbuhi oleh komoditas berbagai makroalga seperti Ulva, Caulerpa, Padina, Hypnea dan lain-lain, dimana hal ini merupakan salah satu indikator bahwa perairan tersebut cocok untuk budidaya $K$. alvarezii. Selain itu sebaiknya perairan tersebut terbebas dari gangguan hewan air lainnya yang bersifat herbivore terutama ikan baronang (Siganus sp), penyu laut (Chelonia midos) dan bulu babi yang dapat memakan tanaman rumput laut Kappaphycus alvarezii (Purwanto et al., 2008).

Dari pernyataan-pernyatan dan pendapat diatas menunjukkan bahwa perairan Ekas tempat dilakukannya penelitian pertumbuhan rumput laut $K$. alvarezii dengan perlakuan ekstrak $S$. aquifolium ini mengindikasikan bahwa perairan Ekas sangat cocok untuk dilakukan budidaya rumput laut baik dari segi kondisi lingkungan kimia, fisika dan biologi maupun dari segi keamanan unit budidaya dan bebrapa pernyataan diatas juga menunjukkan bahwa tidak adanya faktor lain yang mempengaruhi hasil yang tidak sigifikan pada penelitian ini selain dari faktor lama perendaman dan jumlah ekstrak yang digunakan.

\section{KESIMPULAN DAN SARAN}

Kesimpulan penelitian ini adalah:

1. Pemberian ekstrak $S$. aquifolium tidak memiliki pengaruh nyata terhadap pertumbuhan rumput laut $K$. alvarezii.

2. Persentase Kadar karaginan tertinggi dari $K$. alvarezii (53.33\%) terdapat pada perlakuan dengan konsentrasi ekstrak $S$. aquifolium $5 \%$ dengan perendaman selama 90 menit.

\section{UCAPAN TERIMA KASIH}

Ucapan terima kasih disampaikan kepada Kementrian Riset dan Pendidikan Tinggi yang telah membiayai penelitian ini melalui program MP3El tahun anggaran 2015. Ucapan terima kasih juga disampaikan kepada pembudidaya rumput laut di Teluk Ekas yang telah membantu terlaksananya penelitian ini.

\section{DAFTAR PUSTAKA}

Andriana, D. (2005). Pengaruh konsentrasi BAP terhadap multiplikasi tunas dan giberelin terhadap kualitas tunas pisang FHIA-17 in vitro. Skripsi. Program Studi Hortikulturan, Fakultas Pertanian, Institut Pertanian Bogor. Bogor. 35hlm.

Aslan, L. M. (1998). Budidaya rumput laut. Kanisius, Yogyakarta.

Cokrowati, N. (2013). Buku ajar teknologi budidaya rumput laut. Program Studi Budidaya Perairan. Universitas Mataram.

Ditjenkan Budidaya (2004). Petunjuk teknis budidaya rumput laut. Jakarta.

Effendy, H. (2003). Telaah kualitas air. Kansius. Yogyakarta.

Ghazali, M., Muspiah, A., \& Kurnianingsih, R. (2013). Pengaruh ekstrak makroalga terhadap mikropropagasi tanaman pisang secara in vitro. Jurnal Penelitian UNRAM, 17(2), 157162.

Harnoto, Mudeng, J. D., \& Mondoringin, L. L. J. J. (2015). Pertumbuhan rumput laut Kappaphycus alvarezii yang dikultur menggunakan dua jenis tali ris dengan kondisi berbeda. e-Journal Budidaya Perairan, 3(1), 35-42.

Kordi, G. H. (2011). Kiat sukses budidaya rumput laut di laut dan tambak. Jogjakarta: Penerbit Andi. 
Mulyaningrum, S. R. H., Nursyam, H., Risjani, Y., \& Parenrengi, A. (2013). Regenerasi filamen kalus rumput laut Kappaphycus alvarezii dengan formulasi zat pengatur tumbuh yang berbeda. Jurnal Penelitian Perikanan, 1(1), 52-60.

Prihaningrum, Meiyana, M., \& Evalawati (2001). Biologi rumput laut; teknologi budidaya rumput laut (Kappaphycus alvarezii). Petunjuk Tekhnis. Departemen Kelautan dan Perikanan. Direktorat Jendral Perikanan Budidaya. Balai Budidaya Laut. Lampung. 66 hal.

Purwanto, Zatnika, A., \& Istini (2008). Rumput laut. Penebar Swadaya. Jakarta.

Rasjid, Firdaus, Pudu, Dahya, Idris, Herman, \& Subandi (2001). Budidaya rumput laut (Eucheuma cottonii) dengan sistem rakit cara tanam legowo. Balai Pengkajian Teknologi Pertanian. Badan Penelitian dan Pengembangan Pertanian. Departemen Pertanian. Kendari.

Yuliana, Muhtadin, A. S., Tamburu, E., \& Andriani, I. (2014). Pengaruh perendaman Eucheuma spinosum J. agardh dalam larutan pupuk provasolis's enriche seawater terhadap laju pertumbuhan secara in vitro. Jurnal Jurusan Biologi Fakultas Matematika dan IImu Pengetahuan Alam. Universitas Hasanudin. Makasar. 